\title{
MUTU FISIK, FISIOLOGIS, DAN KANDUNGAN BIOKIMIA BENIH TREMA (Trema orientalis Linn. Blume) BERDASARAN TINGKAT KEMASAKAN BUAH
}

\author{
(The Physical, Physiological Quality and Biochemical Content of Trema (Trema orientalis Linn. \\ Blume) Based on Maturity Level)
}

\author{
Naning Yuniarti, Rina Kurniaty, Danu, dan/and Nurmawati Siregar \\ Balai Penelitian dan Pengembangan Teknologi Perbenihan Tanaman Hutan \\ Jl. Pakuan Ciheuleut PO BOX 105; Telp 0251-8327768, Bogor, Indonesia \\ e-mail: naningbtp@yahoo.co.id
}

Naskah masuk: 8 Juni 2016; Naskah direvisi: 14 Juni 2016; Naskah diterima: 1 Desember 2016

\begin{abstract}
Trema orientalis $L$. Blume is a multipurpose plant for all parts of the tree can be used. In order to support the successful development of this plant, seed quality is required, in which one of the requirements for determining quality seed is the seed should come from physiologically fruit mature. The research objective was to determine the quality of the physical, physiological quality, and a biochemical content (fat, carbohydrate and protein) of trema seed based on of fruit maturity. Trema seed used in this research comes from Badung regency, Bali Province. Trema fruit grouped into three color level (green, brown, black). The research design used is CRD (completely randomized design) with a treatment rate of fruit color. Parameters were observed ie. fruit and seed size, the weight of the fruit and seeds, fruit and seed moisture content, content of biochemistry (protein, fat, carbohydrates), germination and speed germination. The results showed: (1) The level of maturity of the fruit significantly affects the physical quality (size of fruit and seeds, fruit weight and seed, the water content of fruits and seeds), physiological (germination, speed of germination), and the content of biochemistry (fats, carbohydrates, protein) trema seed, (2) Quality of physical and physiological seed that comes from the fruit of the black better than the green and chocolate fruit, (3) the content of fats, carbohydrates and protein of trema seed differ for each level of maturity (green, brown, black), (4) Fruit Trema reaching physiological maturity is the fruit of the black with criteria that is: long fruit 3,87 $\pm 0,05 \mathrm{~mm}$ and width 3,41 $\pm 0,02 \mathrm{~mm}$; long seed 2,10 \pm $0,05 \mathrm{~mm}$ and width $1,81 \pm 0.06 \mathrm{~mm} ; 1000$ grain weight of fruit 25.6883 grams; 1000 grain weight of seed 3.8288 $\mathrm{g}$; moisture content of fruit 54,74\%; moisture content of seed 12,03\%; percentage germination $78 \%$; speed of germination 3,05\% / Etmal; content of carbohydrate 20,10\%; content of protein 2,84\% and content of fat $0,65 \%$.
\end{abstract}

Keywords: biochemical, maturity, physical, physiological, Trema (Trema orientalis Linn. Blume),

\begin{abstract}
ABSTRAK
Trema (Trema orientalis Linn. Blume) merupakan tanaman serba guna karena semua bagian pohon dapat digunakan. Dalam pengembangan tanaman ini, diperlukan benih bermutu, dimana salah satu syarat untuk menentukan benih bermutu adalah benih harus berasal dari buah yang sudah masak fisiologis. Tujuan penelitian adalah mengetahui mutu fisik, mutu fisiologis, dan kandungan biokimia (lemak, karbohidrat dan protein) benih trema berdasarkan tingkat kemasakan buah. Benih trema yang digunakan berasal dari Badung, Bali. Buah trema dikelompokkan menjadi 3 warna (hijau, coklat, hitam). Rancangan penelitian menggunakan Rancangan Acak Lengkap dengan parameter yang diamati : ukuran buah dan benih, berat buah dan benih, kadar air buah dan benih, kandungan biokimia (protein, lemak, karbohidrat), daya berkecambah, dan kecepatan berkecambah. Hasil penelitian menunjukkan : (1) Tingkat kemasakan buah berpengaruh nyata terhadap mutu fisik (ukuran buah dan benih, berat buah dan benih, kadar air buah dan benih), fisiologis (daya berkecambah, kecepatan berkecambah), dan kandungan biokimia (lemak, karbohidrat, protein) benih trema, (2) Mutu fisik dan fisiologis benih yang berasal dari buah yang berwarna hitam lebih baik dibandingkan dengan buah berwarna hijau dan coklat, (3) Kandungan lemak, karbohidrat dan protein benih trema berbeda dari masing-masing tingkat kemasakan (hijau, coklat, hitam), (4) Buah trema yang sudah mencapai masak fisiologis adalah buah berwarna
\end{abstract}


hitam, dengan kriteria yaitu : panjang buah 3,87 $\pm 0,05 \mathrm{~mm}$ dan lebar 3,41 $\pm 0,02 \mathrm{~mm}$; panjang benih 2,10 $\pm 0,05$ $\mathrm{mm}$ dan lebar 1,81 $\pm 0,06 \mathrm{~mm}$; berat 1000 butir buah 25,6883 gr; berat 1000 butir benih 3,8288 gr; kadar air buah 54,74\%; kadar air benih 12,03\%; daya berkecambah 78\%; kecepatan berkecambah 3,05\%/Etmal; kandungan karbohidrat 20,10\%; kandungan protein 2,84\%; kandungan lemak 0,65\%.

Kata kunci: biokima, fisik, fisiologis, kemasakan, Trema (Trema orientalis Linn. Blume)

\section{PENDAHULUAN}

Trema (Trema orientalis Linn. Blume) termasuk kedalam famili Ulmaceae merupakan tanaman serba guna karena semua bagian pohon dapat digunakan. Kayunya mengandung kalor $4576 \mathrm{cal} / \mathrm{g}$ (Rostiwati et al., 2006). Selain itu kayu trema dapat digunakan sebagai kayu perkakas, bahan bangunan rangka atap, industri kertas, kayu lapis, korek api dan arang kayu. Daun dan batangnya dapat dijadikan obat herbal, dan kulit batangnya untuk bahan pewarna (Prosea, 1997).

Mengingat potensi yang dimiliki, trema merupakan jenis yang bagus untuk dikembangkan. Dalam rangka menunjang keberhasilan pengembangan tanaman ini, diperlukan benih yang bermutu, dimana salah satu syarat untuk menentukan benih bermutu adalah benih harus berasal dari buah yang masak fisiologis. Apabila benih-benih yang diperoleh tersebut telah masak secara fisiologis maka dapat menghasilkan mutu benih yang baik dan nantinya dapat menghasilkan anakan dan tanaman yang baik. Sebaliknya benih-benih yang belum mencapai masak fisiologis umumnya memiliki mutu yang rendah, mudah terserang jamur dan jarang menghasilkan anakan yang baik. Tingkat kemasakan benih trema berdasarkan warna buah belum diketahui, sehingga diperlukan penelitian untuk menentukan masak fisiologis buah trema.

Dalam penentuan tingkat kemasakan berdasarkan warna buah, maka sifat pewarnaan dari buah muda sampai buah masak dari jenis yang ditangani harus dikenal. Pada umumnya perubahan warna buah terjadi dari warna hijau pada buah yang belum masak ke kuning gelap atau coklat gelap dan bersamaan dengan ini terjadi pengerasan daging buah (Willan, 1985).

Warna buah merupakan petunjuk efektif mendapatkan benih berviabilitas tinggi. Secara visual, benih yang telah masak ditunjukkan dengan perubahan warna kulit buah (Yuniarti et al., 2011).

Benih-benih yang sudah masak secara fisiologis dapat menghasilkan mutu benih yang baik dan nantinya dapat menghasilkan anakan dan tanaman yang baik. Sebaliknya benih- benih yang belum mencapai masak fisiologis umumnya memiliki mutu yang rendah, mudah terserang jamur dan jarang menghasilkan anakan yang baik. Menurut Sudrajat dan Nurhasybi (2007), beberapa cara untuk menentukan indikasi kemasakan buah yang praktis di lapangan antara lain dengan melihat perubahan warna kulit buah, bau, kelunakan buah, berat jenis, dan jatuhnya buah secara 
alami. Untuk mengetahui saat masak fisiologis yang tepat dibutuhkan informasi tentang tingkat kemasakan buah yang akurat, yaitu berdasarkan mutu fisik (ukuran buah dan benih, berat buah dan benih, kadar air buah dan benih), mutu fisiologis (daya berkecambah, kecepatan berkecambah), dan kandungan biokimia (lemak, karbohidrat, protein).

Beberapa contoh buah jenis tanaman yang sudah mencapai masak fisiologis yaitu : (1) Buah damar (Agathis loranthifolia) yang sudah masak fisiologis yaitu buah berwarna hijau tua dan sering disertai bintik-bintik berwarna hitam, mempunyai rata-rata panjang buah lebih besar dari $9,10 \mathrm{~cm}$, diameter buah lebih besar dari 8,40 $\mathrm{cm}$, berat buah lebih besar dari 500,0 gr dan mempunyai kadar air lebih besar dari 35\% (Suyanto, et al., 1990) dan (2) Buah Khaya anthoteca yang sudah masak fisiologis yaitu ukuran buahnya rata-rata berdiameter lebih dari $4,5 \mathrm{~cm}$, mempunyai rata-rata kadar air $76,88 \%$ dan daya berkecambah 93,4\% (Bramasto dan Nurhayati, 1997).

Tingkat warna buah berkaitan erat dengan proses pemasakan buah atau benihnya. Pemasakan benih sendiri selain diawali dengan perkembangan dan pendewasaan struktur tumbuh benih serta penghimpunan cadangan makanan, juga diikuti dengan proses pembentukan senyawa biokimia yang diperlukan untuk pertumbuhan. Oleh karena itu dianggap bahwa benih masak mempunyai mutu benih yang tinggi (Sadjad, 1980), karena struktur tumbuhnya lengkap atau sempurna serta mempunyai cadangan makanan yang cukup. Masak fisiologis buah biasanya ditandai dengan perubahan warna pada kulit buah. Selama proses pemasakan, terjadi perubahan warna buah dari warna hijau menjadi kuning. Selain perubahan fisik, juga diikuti oleh perubahan fisiologis dan kandungan biokimia selama proses pemasakan buah dan benih. Kandungan biokimia yang terkandung dalam benih, misalnya lemak, karbohidrat, dan protein akan mengalami perubahan selama proses pema-sakan atau berdasarkan tingkat kemasakan.

Tujuan dari penelitian ini adalah untuk mengetahui mutu fisik (ukuran buah dan benih, berat buah dan benih, kadar air buah dan benih), fisiologis (daya berkecambah, kecepatan berkecambah), dan kandungan biokimia (lemak, karbohidrat, protein) berdasarkan tingkat kemasakan.

\section{BAHAN DAN METODE}

Tahapan prosedur kerja untuk metodologi adalah sebagai berikut :

1. Penelitian dilakukan selama tiga bulan, yaitu Pebruari sampai dengan April 2015. Pengujian mutu benih dilaksanakan di laboratorium dan rumah kaca Balai Penelitian Teknologi Perbenihan Tanaman Hutan di Bogor. Pengujian analisis kandungan biokimia (karbohidrat, protein, lemak) dilakukan di Laboratorium SeameoBiotrop di Bogor.

2. Benih trema yang digunakan dalam penelitian ini diperoleh dari areal lahan milik masyarakat di Kabupaten Badung, Propinsi Bali. 
3. Buah diunduh dengan cara memanjat pohon atau perontokan sebagian dahan dengan menggunakan galah berkait. Umur pohon yang diunduh yaitu 8 tahun. Jumlah buah yang dibutuhkan adalah sebanyak $3 \mathrm{~kg}$ buah. Buah yang sudah terkumpul kemudian dikelompokan menjadi 3 kelompok tingkat warna buah (hijau, coklat, hitam).

4. Dari masing-masing warna buah diukur ukuran buah dan benih (panjang dan lebar benih) sebanyak masing-masing warna buah 400 butir buah (4 ulangan@100 butir buah) untuk ukuran buah dan 400 butir benih (4 ulangan@100 butir benih) untuk ukuran benih.

5. Pengujian berat 1000 butir buah dari masing-masing warna buah memerlukan jumlah buah sebanyak 800 butir buah dan untuk pengujian berat 1000 butir benih memerlukan benih sebanyak 800 butir benih. Cara pengujian berat 1000 butir buah dan benih menggunakan standar dari ISTA (2006).

6. Pengujian kadar air buah memerlukan jumlah buah sebanyak 40 gram buah (4 ulangan@10 gram buah) dan untuk pengujian kadar air benih memerlukan jumlah benih sebanyak 20 gram benih (4 ulangan@5 gram benih). Cara pengujian kadar air buah dan benih menggunakan standar dari ISTA(2006).

7. Pengujian daya berkecambah dan kecepatan berkecambah dari masing-masing warna buah memerlukan benih sebanyak 400 butir benih (4 ulangan@100 butir benih). Cara pengujian daya berkecambah dan kecepatan berkecambah menggunakan standar dari ISTA(2006).

8. Pengujian untuk analisis kandungan protein menggunakan metode Kjeldhal. Untuk analisis kandungan lemak menggunakan metode Soxhlet. Sedangkan analisis kandungan karbohidrat menggunakan metode Luff Schoorl. Jumlah benih yang diperlukan untuk menguji analisis kandungan protein, lemak, dan karbohidrat yaitu sebanyak 100 gram dari masing-masing warna buah.

9. Rancangan penelitian yang digunakan yaitu RAL (Rancangan Acak Lengkap) terhadap parameter: ukuran buah dan benih, berat buah dan benih, kadar air buah, kadar air benih, kandungan biokimia (protein, lemak, karbohidrat), daya berkecambah, dan kecepatan berkecambah.

10. Data dianalisis dengan analisa sidik ragam (Anova). Apabila berpengaruh nyata dilanjutkan dengan uji Beda Nyata Terkecil (BNT).

\section{HASIL DAN PEMBAHASAN}

\section{A. Hasil}

Rata-rata ukuran buah dan benih (panjang dan lebar) serta berat 1000 butir buah dan benih disajikan pada Tabel 1.

Dari Tabel 1 diketahui bahwa ukuran buah dan benih (panjang dan lebar) yang berasal dari buah berwarna hitam memiliki ukuran yang lebih besar dibandingkan dengan buah yang berwarna hijau dan coklat. Demikian halnya 
dengan berat 1000 butir buah dan benih pada buah yang berwarna hitam memiliki berat yang lebih besar dibandingkan dengan buah berwarna hijau dan coklat.

Hasil ringkasan analisis sidik ragam pengaruh tingkat warna buah terhadap nilai kadar air buah, kadar air benih, daya berkecambah, kecepatan berkecambah, kandungan karbohidrat, lemak, dan protein benih trema disajikan pada Tabel 2 .

Tabel (Table) 1. Rata-rata ukuran buah (panjang dan lebar), ukuran benih (panjang dan lebar), berat 1000 butir buah, dan berat 1000 butir benih trema berdasarkan warna buah (Average fruit size (length and width), seed size (length and width), the1000 grain weight of fruit, and the weight of 1000 grains of seed Trema is based on fruit color)

\begin{tabular}{|c|c|c|c|}
\hline \multirow[b]{2}{*}{$\begin{array}{c}\text { Parameter } \\
\text { (Parameter) }\end{array}$} & \multicolumn{3}{|c|}{ Warna buah (Fruit color) } \\
\hline & $\begin{array}{c}\text { Hijau } \\
\text { (Green) }\end{array}$ & $\begin{array}{l}\text { Coklat } \\
(\text { Brown })\end{array}$ & $\begin{array}{l}\text { Hitam } \\
\text { (Black) }\end{array}$ \\
\hline $\begin{array}{l}\text { Panjang buah (Length } \\
\text { of fruit) (mm) }\end{array}$ & $\begin{array}{c}3,74 \pm \\
0,02\end{array}$ & $\begin{array}{c}3,75 \pm \\
0,03\end{array}$ & $\begin{array}{c}3,87 \pm \\
0,04\end{array}$ \\
\hline $\begin{array}{l}\text { Lebar buah (Width of } \\
\text { fruit) (mm) }\end{array}$ & $\begin{array}{c}3,37 \pm \\
0,02\end{array}$ & $\begin{array}{c}3,39 \pm \\
0,02\end{array}$ & $\begin{array}{c}3,41 \pm \\
0,02\end{array}$ \\
\hline $\begin{array}{l}\text { Panjang benih Length } \\
\text { of seed })(\mathrm{mm})\end{array}$ & $\begin{array}{c}1,97 \pm \\
0,05\end{array}$ & $\begin{array}{c}2,00 \pm \\
0,03\end{array}$ & $\begin{array}{c}2,10 \pm \\
0,05\end{array}$ \\
\hline $\begin{array}{l}\text { Lebar benih (Width of } \\
\text { seed) }(\mathrm{mm})\end{array}$ & $\begin{array}{c}1,75 \pm \\
0,05\end{array}$ & $\begin{array}{c}1,77 \pm \\
0,04\end{array}$ & $\begin{array}{c}1,81 \pm \\
0,06\end{array}$ \\
\hline $\begin{array}{l}\text { Berat } 1000 \text { butir buah } \\
\text { (gram) (The } 1000 \\
\text { grain weight of fruit) }\end{array}$ & 15,578 & 25,158 & 25,69 \\
\hline $\begin{array}{l}\text { Berat } 1000 \text { butir } \\
\text { benih (gram) (The } \\
\text { weight of } 1000 \\
\text { grains of seed) }\end{array}$ & 3,50 & 3,66 & 3,83 \\
\hline $\begin{array}{l}\text { Kadar air buah (\%) } \\
\text { (Moisture content } \\
\text { of fruit) }\end{array}$ & $\begin{array}{c}67,58 \pm \\
2,77\end{array}$ & $\begin{array}{c}60,00 \pm \\
9,18\end{array}$ & $\begin{array}{c}54,74 \pm \\
8,39\end{array}$ \\
\hline $\begin{array}{l}\text { Kadar ir benih }(\%) \\
\text { (Moisture content } \\
\text { of seed) }\end{array}$ & $\begin{array}{c}14,12 \pm \\
0,31\end{array}$ & $\begin{array}{c}13,22 \pm \\
0,16\end{array}$ & $\begin{array}{c}12,03 \pm \\
0,09\end{array}$ \\
\hline
\end{tabular}

Tabel(Table) 2. Ringkasan analisis sidik ragam pengaruh warna buah terhadap kadar air buah, kadar air benih, daya berkecambah, kecepatan berkecambah, kandungan karbohidrat, lemak dan protein benih trema (Summary of analysis of variance of the influence of fruit color to fruit moisture content, seed moisture content, germination percentage, speed of germination, carbohydrate, fat and protein content of trema seed)

\begin{tabular}{|c|c|c|c|}
\hline No. & $\begin{array}{l}\text { Parameter } \\
\text { (Parameter) }\end{array}$ & $\begin{array}{c}\text { F Hitung } \\
\text { (FCalculation })\end{array}$ & $\begin{array}{c}\text { F Tabel } \\
(5 \%) \\
(F \text { Table })\end{array}$ \\
\hline 1. & $\begin{array}{l}\text { Kadar air buah } \\
\text { (Fruit moisture } \\
\text { content) }\end{array}$ & $5,31 *$ & 5,14 \\
\hline 2. & $\begin{array}{l}\text { Kadar air benih } \\
\text { (Seed moisture } \\
\text { content) }\end{array}$ & $100,05 *$ & 5,14 \\
\hline 3. & $\begin{array}{l}\text { Daya } \\
\text { berkecambah } \\
\text { (Germination } \\
\text { percentage) }\end{array}$ & $24,23 *$ & 5,14 \\
\hline 4. & $\begin{array}{l}\text { Kecepatan } \\
\text { berkecambah } \\
\text { (Speed of } \\
\text { germination) }\end{array}$ & $29,31 *$ & 5,14 \\
\hline 5. & $\begin{array}{l}\text { Kandungan } \\
\text { karbohidrat } \\
\text { (Carbohydrate } \\
\text { content) }\end{array}$ & $42147,00 *$ & 5,14 \\
\hline 6. & $\begin{array}{l}\text { Kandungan } \\
\text { lemak (Fat } \\
\text { content) }\end{array}$ & $50,25 *$ & 5,14 \\
\hline 7. & $\begin{array}{l}\text { Kandungan } \\
\text { protein } \\
\text { (Protein content) }\end{array}$ & $22,75 *$ & 5,14 \\
\hline
\end{tabular}

Keterangan $($ Notes $): *=$ Nyata pada tingkat kepercayaan $95 \%$ (* = Significant at $95 \%$ confidencelevel) 
Berdasarkan hasil sidik ragam menunjukkan bahwa perlakuan tingkat warna buah berpengaruh nyata terhadap nilai kadar air buah, kadar air benih, daya berkecambah, kecepatan berkecambah, kandungan karbohidrat, lemak, dan protein benih trema. Untuk mengetahui lebih lanjut perlakuan yang menimbulkan perbedaan yang nyata, dilakukan uji beda Duncan (Gambar 1 dan Gambar 2).

\section{A. Pembahasan}

Dari Tabel 1 menunjukkan bahwa ukuran buah dan ukuran benih pada buah yang berwarna hijau mempunyai ukuran yang paling kecil dibandingkan dengan buah yang berwarna coklat dan hitam. Buah berwarna hitam mempunyai ukuran paling besar. Dilihat dari berat 1000 butir buah dan benih, menunjukkan bahwa buah berwarna hitam mempunyai berat yang paling tinggi dibandingkan dengan buah berwarna coklat dan hijau. Hal ini sesuai dengan Pendapat Bewley dan Black (1985), yang menyatakan secara umum benih mengalami peningkatan bobot kering sampai benih mencapai masak fisiologis. Menurut Suyanto, et al. (1999) dalam hal karakteristik ukuran buah, baik mengenai panjang, diameter serta berat buah jenis damar, tampak bahwa semakin tinggi tingkat kemasakannya, maka ukuran buah semakin besar.
Pada Tabel 2 diketahui bahwa tingkat kemasakan buah yang dicerminkan oleh perubahan warna kulit buah berpengaruh terhadap kadar air buah, kadar air benih, daya berkecambah, kecepatan berkecambah, dan kandungan biokimia (karbohidrat, lemak, dan protein) benih trema. Menurut Yuniarti (2006) warna buah dapat dijadikan sebagai indeks kemasakan buah jenis saga pohon. Benih yang berasal dari buah/polong berwarna coklat yang sudah merekah memiliki viabilitas yang lebih baik apabila dibandingkan dengan benih-benih yang berasal dari buah/polong yang berwarna hijau dan coklat yang belum merekah.

Pada semua tingkat kemasakan berdasarkan warna buah tersebut, benih dapat berkecambah karena pada berbagai tingkat kemasakan benih tersebut embrio dan cadangan makanannya telah terbentuk. Terjadinya perbedaan daya berkecambah antara warna buah / tingkat kemasakan benih tersebut menurut Sutopo (2010) adalah karena cadangan makanan yang terdapat pada benih yang belum masak masih belum cukup tersedia bagi pertumbuhan embrio, selengkap yang tersedia pada benih yang masak. Jadi tingkat warna buah berkaitan erat dengan proses pemasakan buah atau benihnya. 


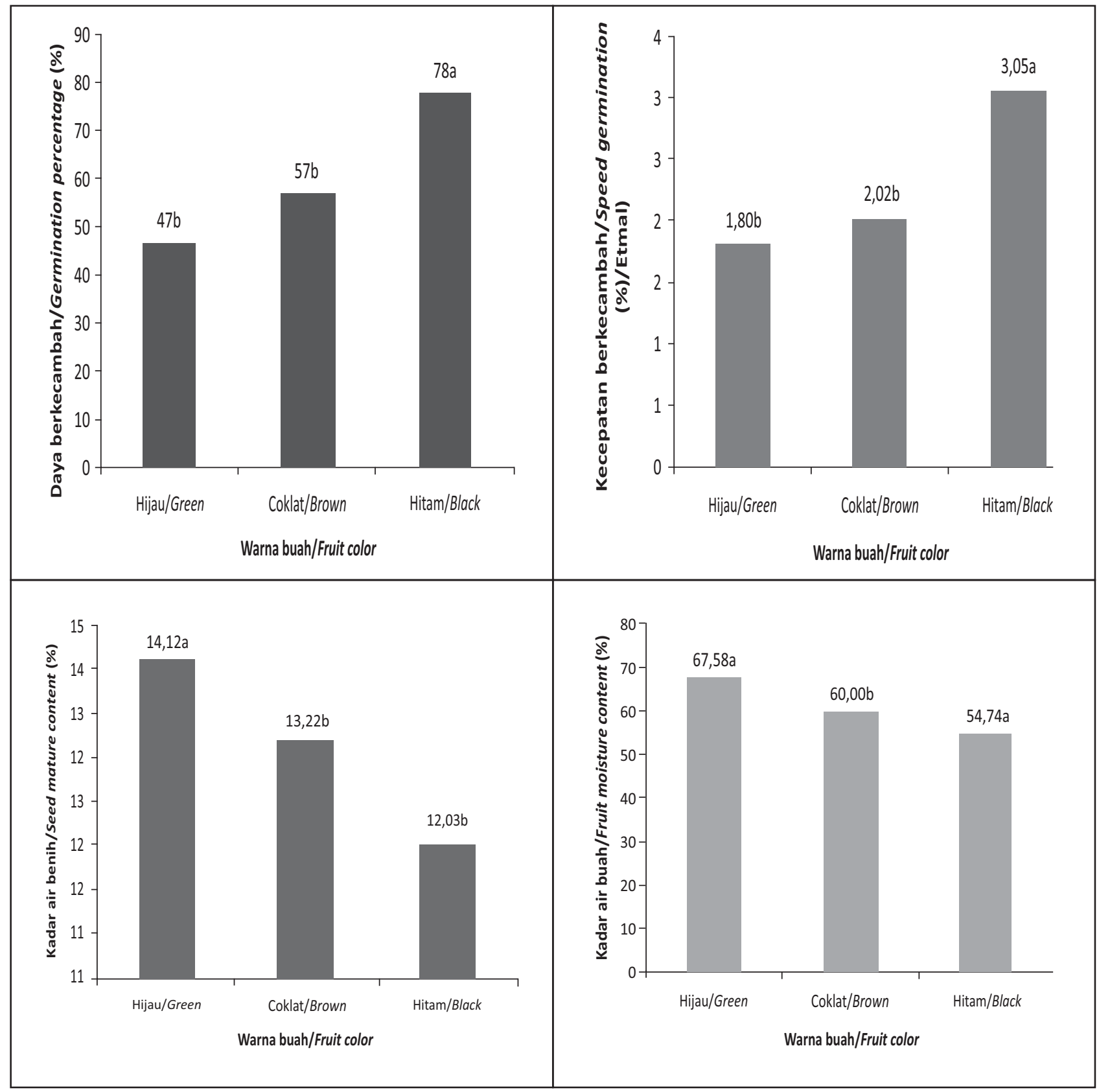

Keterangan(Notes): Angka-angka yang diikuti oleh huruf yang sama menunjukkan tidak adanya perbedaan nyata pada tingkat kepercayaan 95\% (Values followed by the same letter are not significantly different at $95 \%$ confidencelevel)

Gambar(Figure) 1. Rata-rata kadar air buah, kadar air benih, daya berkecambah dan kecepatan berkecambah benih trema berdasarkan warna buah (Uji Duncan) (Average of germination percentage and speed of germination of trema seed based on fruit color (Duncan Test)) 
Pemasakan benih sendiri selain diawali dengan perkembangan dan pendewasaan struktur tumbuh benih serta penghimpunan cadangan makanan, juga diikuti dengan proses pembentukan senyawa biokimia yang diperlukan untuk pertumbuhan (Sutopo, 2010). Oleh karena itu dianggap bahwa benih masak mempunyai mutu benih yang tinggi, karena struktur tumbuhnya lengkap atau sempurna serta mempunyai cadangan makanan yang cukup. Selama proses pemasakan, terjadi perubahan warna buah dari warna hijau menjadi coklat.

Dari Gambar 1 terlihat terjadi adanya penurunan nilai kadar air buah dan benih dari buah berwarna hijau, ke coklat sampai hitam. Hal ini berarti buah yang masih belum masak fisiologis (warna hijau) mempunyai kadar air buah dan kadar air benih paling tinggi kemudian nilainya menurun pada warna buah coklat hingga titik nilai terendah pada buah berwarna hitam. Ada beberapa fase untuk mencapai suatu tingkat kemasakan benih, yaitu fase pembuahan, fase penimbunan zat makanan dan fase pemasakan. Fase pertumbuhan dimulai sesudah terjadi proses penyerbukan, yang ditandai dengan pembentukan-pembentukan jaringan dan kadar air yang tinggi. Fase penimbunan zat makanan ditandai dengan kenaikan berat kering benih, dan turunnya kadar air. Pada fase pemasakan, kadar air benih akan mencapai keseimbangan dengan kelembaban udara di luar; dan setelah mencapai tingkat masak benih; berat kering benih tidak akan banyak mengalami perubahan (Sutopo, 2010).
Dilihat dari nilai daya berkecambah dan kecepatan berkecambah (Gambar 1), terjadi sebaliknya yaitu adanya peningkatan nilai dari buah berwarna hijau ke coklat sampai hitam. Hal ini menunjukkan bahwa buah trema yang sudah mencapai masak fisiologis didapatkan pada benih yang berasal dari buah yang berwarna hitam. Daya berkecambah yang dihasilkan berbeda dari masing-masing tingkat kemasakan (warna buah). Hal ini sesuai dengan pendapat Kamil (1982) yang menyatakan bahwa benih dapat berkecambah jauh sebelum kemasakan fisiologis tercapai. Hal ini juga terjadi pada benih trema.

Perbedaan itu antara lain disebabkan karena cadangan makanan yang terdapat pada benih yang belum masak masih belum cukup tersedia bagi pertumbuhan embrio, lain halnya pada benih yang telah masak. Menurut Sutopo (2010), adanya perbedaan daya berkecambah antar warna buah/tingkat kemasakan benih tersebut karena cadangan makanan yang terdapat pada benih yang belum masak masih belum cukup tersedia bagi pertumbuhan embrio dan semakin lengkap tersedia pada benih yang masak. Kondisi ini menggambarkan hubungan yang erat antara proses pemasakan buah dengan benihnya. Schmidt (2000) menyebutkan bahwa kualitas benih ditentukan viabilitas dan vigor benih, hal ini berkaitan erat dengan tingkat kemasakan fisiologis benih, sehingga benih yang di panen pada saat masak fisiologis akan menghasilkan viabilitas dan vigor benih yang lebih tinggi. 
Menurut Yuniarti (2006), benih kenari yang berasal dari buah yang sudah mencapai masak fisiologis akan menghasilkan nilai daya berkecambah paling besar dibandingkan buah yang belum masak. Selain daya berkecambah, tingkat kemasakan buah juga dilihat dari nilai kadar air benihnya. Buah yang masak fisiologis mempunyai nilai kadar air benih yang lebih rendah dibandingkan buah yang belum masak.

Pada Gambar 2 terlihat adanya perbedaan kandungan karbohidrat, protein dan lemak dari perubahan buah berwarna hijau, ke coklat sampai hitam. Dilihat dari kadar karbohidrat dan protein menunjukkan adanya peningkatan dari buah berwarna hijau ke coklat sampai hitam. Sedangkan dari kandungan lemak adalah sebaliknya yaitu terjadinya penurunan dari buah berwarna hijau ke coklat sampai hitam. Seiring dengan meningkatnya kandungan karbohidrat dan protein dari benih trema juga terjadi peningkatan daya berkecambahnya.
Pada buah yang sudah mencapai masak fisiologis (buah warna hitam) memiliki kandungan karbohidrat dan protein yang lebih banyak dibandingkan dengan buah yang belum masak (buah warna hijau dan coklat). Hal ini disebabkan karena cadangan makanan dan energi yang terbentuk pada buah yang sudah masak adalah sudah semakin lengkap dan sudah memenuhi untuk kebutuhan pertumbuhan embrio. Sedangkan kandungan lemak yang dimiliki oleh buah yang sudah masak adalah lebih sedikit dibandingkan dengan buah yang belum masak. Hal ini bisa disebabkan karena pada awal proses pemasakan buah (warna hijau) metabolit awal yang terbentuk adalah lemak. Jadi hal ini yang menyebabkan kandungan lemak pada buah warna hijau paling tinggi. Kemudian seiring dengan proses pemasakan buah tahap selanjutnya terjadi penurunan kandungan lemak pada buah berwarna coklat sampai buah berwarna hitam yang memiliki kandungan lemak paling sedikit. 


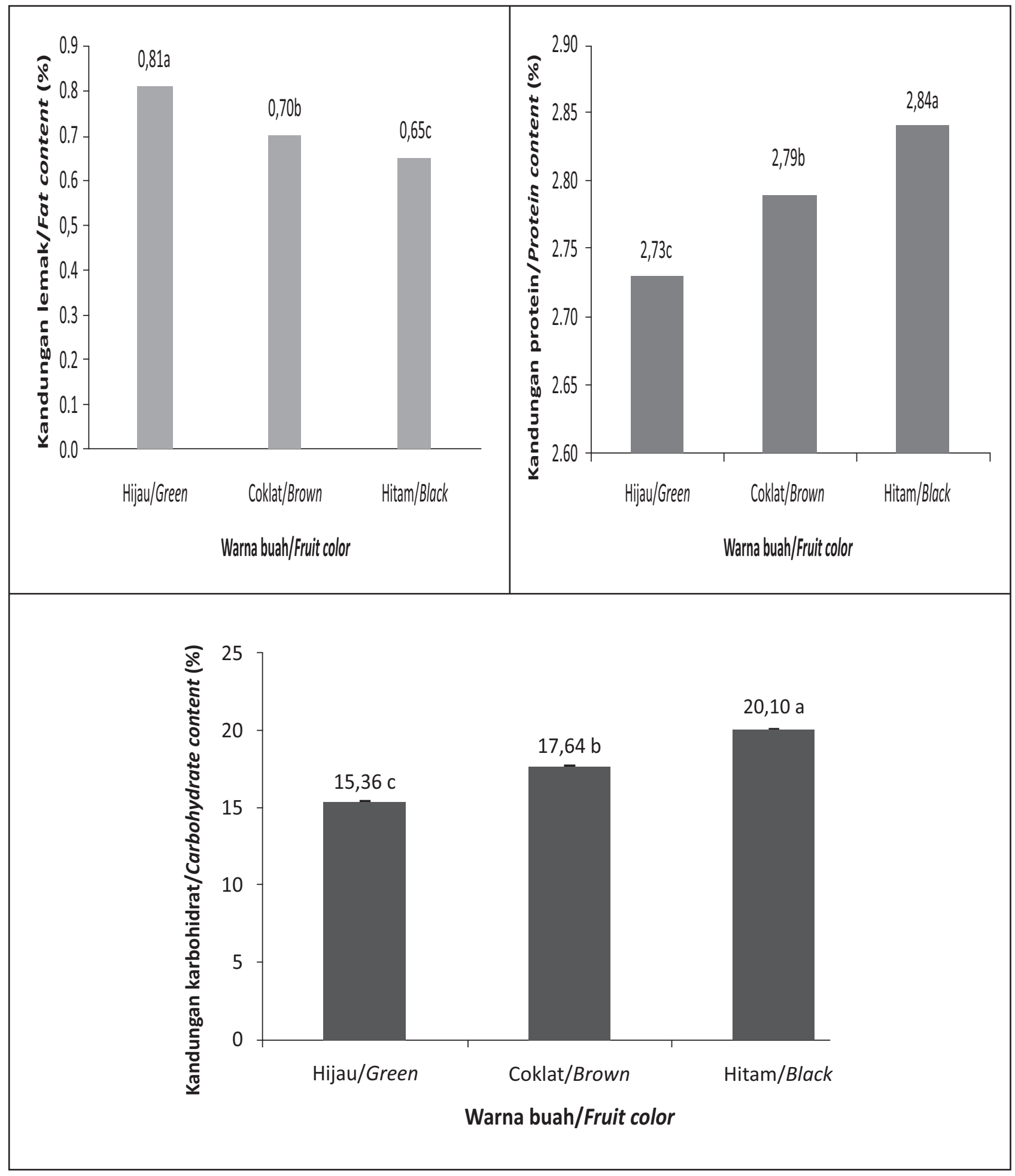

Keterangan(Notes): Angka-angka yang diikuti oleh huruf yang sama menunjukkan tidak adanya perbedaan nyata pada tingkat kepercayaan 95\% (Values followed by the same letter are not significantly different at $95 \%$ confidencelevel)

Gambar(Figure) 2. Rata-rata kandungan lemak, protein, dan karbohidrat benih trema berdasarkan warna buah (Uji Duncan) (Average of fat, protein, and carbohydrate content of trema seed based on fruit color (Duncan Test)) 
Karbohidrat berfungsi sebagai cadangan makanan dan energi dibutuhkan untuk pertumbuhan dinding sel baru (Bewley dan Black, 1985). Protein di dalam biji sebagian besar terdapat di dalam embrio dan kotiledon terutama dalam bentuk asam amino. Di dalam proses perkecambahan protein juga berfungsi untuk pembentukan protoplasma sel untuk permulaan pertumbuhan (Kamil, 1979). Disamping sebagai cadangan makanan protein juga merupakan bagian utama di dalam struktur enzim-enzim yang berperan dalam proses perkecambahan (Bewley dan Black, 1994). Lemak di dalam benih sebagian besar terdapat pada embrio dan kotiledon dan pada saat proses perkecambahan digunakan sebagai cadangan makanan dan energi sebelum proses fotosintesa dimulai (Kamil, 1979). Benih yang berasal dari buah berwarna hitam mempunyai kandungan lemak paling rendah dibandingkan dengan warna hijau dan coklat. Seiring dengan menurunnya kandungan lemak diikuti dengan meningkatnya nilai daya berkecambah. Semakin tinggi kandungan lemak pada benih akan menyebabkan nilai daya berkecambah menurun. Benih dengan kandungan lemak tinggi akan kehilangan viabilitas dan kemampuan berkecambah (Balesevic-Tubic et al., 2007).

Meningkatnya kandungan lemak bisa menyebabkan adanya jamur (Worang et al., 2008). Kandungan asam lemak yang tinggi di dalam benih juga merupakan indikasi terjadinya proses respirasi yang tinggi yang menyebabkan benih kehilangan energi untuk perkecambahan (Liu et al., 2006).
Jadi tingkat warna buah berkaitan erat dengan proses pemasakan buah atau benihnya. Pemasakan benih sendiri selain diawali dengan perkembangan dan pendewasaan struktur tumbuh benih serta penghimpunan cadangan makanan, juga diikuti dengan proses pembentukan senyawa biokimia yang diperlukan untuk pertumbuhan. Oleh karena itu dianggap bahwa benih masak mempunyai mutu benih yang tinggi (Sadjad, 1980), karena struktur tumbuhnya lengkap atau sempurna serta mempunyai cadangan makanan yang cukup. Selama proses pemasakan, terjadi perubahan warna buah dari warna hijau menjadi coklat. Berdasarkan hasil tersebut di atas maka dapat dikatakan bahwa warna buah dapat dijadikan sebagai indeks kemasakan buah.

Masak fisiologis buah biasanya ditandai dengan perubahan warna pada kulit buah, penurunan kadar air buah dan pada saat ini pengangkutan bahan makanan ke dalam buah terhenti sehingga ukuran buah mencapai maksimum, viabilitas dan vigor maksimum sehingga kualitas benih tertinggi diperoleh pada saat masak fisiologis (Sutopo, 2010). Proses masak fisiologis pada buah dan biji biasanya terjadi secara bersamaan, sehingga waktu masaknya buah biasanya bersamaan dengan waktu masaknya biji. Tahap masak fisiologis pada buah terdiri proses fisiologis, biokimia dan dehidrasi (penurunan kadar air benih). Pada proses fisiologis dan biokimia terjadi peningkatan pembentukan cadangan makanan dan hormon pengatur tumbuh (Schmidt, 2000). 
Pemasakan benih selain diawali dengan perkembangan dan pendewasaan struktur tumbuh benih serta perhimpunan cadangan makanan, juga diikuti dengan proses pembentukan senyawa biokimia yang diperlukan untuk pertumbuhan. Kandungan senyawa-senyawa yang terdapat di dalam benih terutama karbohidrat, protein dan lemak berpengaruh terhadap daya berkecambah benih (Kamil, 1979, Bewley dan Black, 1985).

\section{KESIMPULAN}

Tingkat kemasakan buah trema berpengaruh nyata terhadap mutu fisik (ukuran buah dan benih, berat buah dan benih, kadar air buah dan benih), fisiologis (daya berkecambah, kecepatan berkecambah), dan kandungan biokimia (lemak, karbohidrat, protein) benih trema. Mutu fisik dan fisiologis benih yang berasal dari buah yang berwarna hitam lebih baik dibandingkan dengan buah berwarna hijau dan coklat. Kandungan lemak, karbohidrat dan protein benih trema berbeda dari masingmasing tingkat kemasakan (hijau, coklat, hitam). Buah trema yang sudah mencapai masak fisiologis yaitu buah berwarna hitam.

\section{UCAPAN TERIMAKASIH}

Penulis mengucapkan terima kasih kepada :

1. Bapak I Nyoman Sutrisna di Dusun Banjar Tinggan, Desa Pelagan, Kecamatan Petang, Kabupaten Badung, Propinsi Bali yang telah memberikan materi benih untuk kegiatan penelitian.
2. Ateng Rahmat Hidayat, S.Hut yang telah banyak membantu dalam pelaksanaan pengujian benih di laboratorium dan rumah kaca Balai Penelitian dan Pengembangan Teknologi Perbenihan Tanaman Hutan di Bogor.

3. Laboratorium Seameo-Biotrop di Bogor yang telah membantu dalam analisis pengujian kandungan lemak, karbohidrat dan protein benih trema.

\section{DAFTAR PUSTAKA}

Balesevic-Tubic, S, Tatic, M, Miladinovic, J, Pucarevic, M .(2007). Changes of faty acids content and vigour of sunflower seed during natural aging. Helia 30(47), 61-67.

Bewley, J.D and M. Black. (1985). Physiology and Biochemistry of seed. Vol.I. New York: Springer Verlag.

Bewley, J.D and M. Black. (1994). Physiology and seed development and germination. New York: Plenum Press.

Bramasto, Y. dan Nurhayati, K. (1996). Pengaruh tingkat masak fisiologis dan cara ekstraksi terhadap daya berkecambah dan kecepatan berkecambah benih Khaya anthoteca (Laporan Uji Coba no. 72): Balai Teknologi Perbenihan Bogor.

Kamil, J.(1979). Teknologi Benih Jilid I. Padang: Angkasa Raya.

Kamil, J.(1982). Teknologi Benih I. Bandung: Penerbit Angkasa.

Liu M-S,Chang C-Y, Lin T-P.(2006). Comparison of phospholipids and their fatty acids in recalcitrant and orthodox seeds. Seed Science and Technology, 34: 443-452.

Prosea. (1997). Auxiliary plant no II. Editor : I.F. Hanum dan L.J.G. Van Der Maesen. Backhuys Publisher-Leiden, Netherlands. p: 252-255.

Rostiwati, T, Y. Heryati, S. Bustomi. (2006). Review hasil litbang kayu energi dan turunannya. Pusat Penelitian Dan Pengembangan Hutan Tanaman. 
Sadjad, S. (1980). Panduan pembinaan mutu benih tanaman kehutanan Indonesia. Kerjasama Ditjen Reboisasi dan Rehabilitasi Lahan Dept. Kehutanan dengan Institut Pertanian Bogor.

Schmidt, L.( 2000). Pedoman penanganan benih tanaman hutan tropis dan sub tropis. Direktorat Jenderal Rehabilitasi Lahan dan Perhutanan Sosial - Indonesia Forest Seed Project. PT. Gramedia. Jakarta.

Schmidt, L. (2000). Pedoman penanganan benih tanaman hutan tropis dan sub tropis (Terjemahan). Kerjasama Direktorat Jenderal RLPS dan IFSP. PT. Gramedia. Jakarta. 530 hal. (terjemahan).

Sudjindro. (1994). Indikasi kemunduran viabilitas oleh dampak guncangan pada benih kenaf (Hibiscus cannabinus L.). Disertasi Program Pasca Sarjana. IPB.

Sutopo, L. (2010). Teknologi Benih. Edisi Revisi. Jakarta: PT. Raja Grafindo Persada.

Sudrajat, D.J. \& Nurhasybi. (2007). Produksi dan pengujian mutu benih tanaman hutan. Prosiding Seminar "Teknologi Perbenihan Untuk Peningkatan Produktifitas Hutan Tanaman Rakyat di Sumatera Barat. 7 November 2007. Solok.
Suyanto, H., Kusmintarjo \& Kartiko, H.D.P. (1999). Penentuan karakteristik masak fisiologis buah damar (Agathis loranthifolia Salisb). Laporan Uji Coba No. 72. Balai Teknologi Perbenihan Bogor.

Willan, R.L. (1985). A guide to forest seed handling.FAO for Paper. Rome.

Worang, R.L., O.S. Dharmaputra, R. Syarief \& Miftahudin. (2008). The quality of physic nut (Jatropha curcas L.) seeds packed in plastic material during storage. Biotropia, vol. 15 no. 1, 2008: 25-36.

Yuniarti, N. (2006). Kriteria masak fisiologis buah dan berat 1000 butir benih kenari (Canarium $s p$.). Prosiding Seminar Benih Untuk Rakyat: Menghasilkan dan Menggunakan Benih Bermutu Secara Mandiri. 4 Desember 2006. Bogor.

Yuniarti, N., E. Suita, M. Zanzibar, \& Nurhasybi. (2011). Teknik penanganan benih tanaman hutan. Prosiding Seminar Hasil-Hasil Penelitian "Teknologi Perbenihan Untuk Meningkatkan Produktivitas Hutan Rakyat di Propinsi Jawa Tengah.”20 Juli 2011. Semarang. 